\title{
CIEN AÑOS DE EDUCACIÓN \\ EN AGUASCALIENTES
}

GILBERTO GUEVARA NIEBLA

Director del Instituto Mexicano de Investigaciones Educativas

Salyador Camacho Sandoval y Yolanda Padilla RanGEL, Vaivenes de Utopra. Historia de la educación en Aguascalientes en el siglo XX, 4 tomos, Instituto de Educación de Aguascalientes, 1997.

1. $\mathrm{n}$ los dos primeros tercios del siglo $\mathrm{XX}$ la historia de México fue enriquecida por aportaciones relevantes de investigadores que exploraron la época colonial y el siglo XIX. Sus trabajos arrojaron importante luz sobre la fundación de la nación y la gestación de nuestra nacionalidad. Los estudios del siglo XX, en cambio, fueron menos abundantes. A nuestra clase académica no le era fácil tomar distancia crítica ante un acontecimiento que, aunque ocurrió en la parte inicial de la centuria, siguió de muchas maneras determinándonos.

Me refiero, desde luego, a la Revolución Mexicana. No fue sino hasta los años
60 cuando aparecieron publicadas importantes aportaciones historiográficas que comenzaron a revalorar, con distancia crítica, los sucesos de 1910-1917 y el desarrollo del poder político desde entonces hasta nuestros días. En el marco de este saldo de cuentas intelectual, se comenzó a recuperar, con toda su riqueza, uno de los rubros más interesantes de la obra postrevolucionaria: me refiero a la educación.

La empresa educativa de México durante el siglo XX representa la continuación, por otros medios, del esfuerzo iniciado en el siglo XIX para construir la nación. Como se sabe, el Estado es el constructor de las naciones y no la nación la constructora del Estado. Al consumarse el Risorgimiento con la unidad de Italia, Mariano d’Asseglio pronunció su célebre frase: "Hemos hecho a Italia, ahora nos falta hacer a los italianos". En el caso de México esta fórmula no es menos cierta. 
Podemos asumir que el Estado nacional se creó con la República Restaurada, pero ésta no simbolizó realmente el final sino el verdadero principio de la construcción nacional. Tras armar el cimiento estatal, se comenzó a erigir el edificio. La parte que faltaba por construir representaba, al menos, tres problemas políticos cruciales: 1. Encontrar un equilibrio entre el gobierno central y las élites locales; 2 . Construir un conjunto de agencias intermediarias entre el Estado y la sociedad, y 3. Formar una ciudadanía que compartiera la confianza en esas agencias (lealtad hacia el Estado) y la identidad nacional.

Sobre todo esto último: la construcción de México exigía fundir dentro de un molde institucional y un patrón cultural a los habitantes del territorio reconocido como mexicano. El instrumento principal para consumar este propósito fue la escuela. Las primeras disposiciones de la República Restaurada fueron educativas (Ley Orgánica de 1867) y ellas inauguraron la época de oro de la educación decimonónica. La Revolución Mexicana, con José Vasconcelos a la cabeza, continuó esa tarea edificadora y podemos decir que, en estricto sentido, esta gigantesca obra de construcción del imaginario nacional todavía no concluye, y habrá quien sostenga que aún falta mucho para realizar el ideal de nación de nuestros próceres liberales. Quizás. Pe- ro se puede constatar que desde 1867 hasta nuestros días ha habido importantes jalones históricos en la dirección que ellos fijaron.

El libro Vaivenes de utopía. La educación en Aguascalientes en el siglo XX ilustra las vicisitudes que conoció el proyecto nacional en esta centuria, aunque debo destacar que estamos ante una obra excepcional pues, además de que ofrece una visión panorámica, rigurosa y bien documentada del desarrollo político y educativo de México, tiene el atractivo singular de que la mirada del narrador no se ubica, como suele suceder, en el centro del país, sino en uno de sus estados. Este estado es, por añadidura, una entidad con una vigorosa tradición educativa. El libro tiene, además, entre sus principales cualidades, una escritura clara, directa y amena, de tal modo que el lector puede disfrutar con él de una apasionanate lectura, plena de sorpresas y hechos interesantes. Aguascalientes se convierte en esta obra en un escenario amplificado en el que el lector puede presenciar, episodio tras episodio, el desenvolvimiento de las luchas políticas y educativas del México moderno. Enfrentamientos, conflictos ideológicos, desaveniencias gremiales y hasta situaciones paradójicas o absurdas creadas por la ambición o la estulticia de los actores, todo esto integra el largo y abigarrado cortejo de acontecimientos que 
se narran en esta obra. Este recuento, profusamente documentado, tiene sin embargo un eje conceptual que orienta el conjunto de la narración: las relaciones entre el centro y la periferia, en las que se proyectan, nítidamente, los encuentros y desencuentros de dos visiones opuestas de la nación: la visión federalista y la visión centralista.

La historia de México entera puede ser vista a través de la pugna entre estas dos visiones. El ideal federalista, como todos sabemos, animó a las fuerzas progresistas durante la primera parte del siglo XIX, pero fue sustituido en los hechos por el centralismo. La Revolución Mexicana (1910-1917) significó un gran salto histórico, pero sin abandonar, esencialmente, el sendero preestablecido por la dictadura. Se inauguró, en cambio, una nueva época caracterizada por un centralismo político sustentado en una forma inédita de relaciones Estado-sociedad, en donde las masas populares -campesinas y obreras- tuvieron un protagonismo destacado y, no obstante, subordinado. En la obra de Yolanda Padilla Rangel y Salvador Camacho Sandoval se presentan, en sucesión creciente, cada uno de los pasos que se dieron bajo el régimen revolucionario. El primero fue la creación de la Secretaría de Educación Pública (SEP) en 1921 y la campaña educativa de Vasconcelos. Des- pués vinieron los primeros afanes modernizadores y las pugnas en torno a la escuela de la acción (1925), la Guerra Cristera (1926-1929) y la educación socialista (1934). Más tarde (1940) comenzaría la expansión burocrática y centralizadora del sistema educativo nacional, en donde la SEP tuvo por compañero inseparable al Sindicato Nacional de Trabajadores de la Educación (SNTE). La política de expansión escolar, simbolizada por el Plan de Once Años (1960), conduciría más tarde a una crisis que se anunció en la esfera política por los acontecimientos de 1968, pero que tuvo además otras expresiones significativas: la presencia en el sistema de un malestar difuso, una declinación en los aprendizajes y la agudización de los conflictos laborales. Este ciclo declinante se trataría de cerrar con nuevas medidas descentralizadoras y con las acciones recientes para modernizar y federalizar el sistema educativo. En esta última parte, la obra abunda en información. En fin, quien realiza este largo recorrido comprueba que el siglo Xx mexicano entero fue una experiencia arquetípica de desarrollo fundado en el centralismo y, aunque la historia que reseñamos es un estudio científico que no pretende tomar posición ante los hechos, inevitablemente su mero repaso suscita en el lector sentimientos de simpatía a favor de la democratización del sistema educativo. 
